\title{
Changes in certain serum and faeces parameters in weaned piglets as a response to nutritional stress
}

\author{
M. Habeanu ${ }^{1 \#}$, N.A. Lefter ${ }^{1}$, A. Gheorghe ${ }^{1}$, C. Tabuc ${ }^{1}$, A. Untea ${ }^{1}$, I. Surdu' ${ }^{2}$, \\ G. Ciurescu ${ }^{1}$, C.G. Balan ${ }^{3} \&$ C. Dragomir ${ }^{1}$ \\ ${ }^{1}$ National Research-Development Institute for Animal Biology and Nutrition Balotesti, 077015, Romania \\ ${ }^{2}$ Institute of Life Science, Vasile Goldis Western University of Arad, 310414, Arad County, Romania \\ ${ }^{3}$ Synevovet laboratory, 077040, Bucharest, Romania
}

(Received 5 December 2014; Accepted 17 March 2015; First published online 3 June 2015)

\begin{abstract}
Copyright resides with the authors in terms of the Creative Commons Attribution 2.5 South African License.
See: http://creativecommons.org/licenses/by/2.5/za

Condition of use: The user may copy, distribute, transmit and adapt the work, but must recognize the authors and the South African Journal of Animal Science.
\end{abstract}

\begin{abstract}
Weaning is associated with several stress factors and their effects on the piglet's body are fairly well known. Thus, changes were estimated in certain serum and faecal parameters after weaning owing to dietary protein level, though essential amino acid (AA) levels were maintained or reduced. Eighteen Topigs piglets were assigned randomly to three homogenous groups. The dietary protein level was reduced by $10 \%$ in diets 1 and 2 compared with diet C. Diet 1 had similar levels of essential AA to diet C, while the levels of essential AA in diet 2 were reduced by $10 \%$. Blood samples were collected by jugular venipuncture in the farrowing unit on four occasions: before and after separation from the sow; the day after transfer to the nursery; and seven days after weaning. Faecal excreta were collected daily. No major health problems arose, and total pathogen germs were not different among treatments. Cortisol concentration reached similar values to those from the farrowing unit seven days after weaning. Whatever the diet, vitamin $\mathrm{E}$ in plasma decreased significantly in the first seven days post weaning. The reduction of dietary protein, as well as essential AAs, adversely affected the concentration of $\mathrm{Cu}$ (by 17.3\%) in plasma. Selenium concentration in plasma increased slightly, irrespective of diet. The authors conclude that providing dietary protein at a particular level (diet 1), while maintaining AAs at normal level, limits faecal nitrogenous content without significantly modifying stress indicators (except vitamin E) or faecal composition.
\end{abstract}

Keywords: Germs, piglets, protein, stress indicators, weaning

Corresponding author: mihaela.habeanu@ibna.ro

\section{Introduction}

Little is known about the interrelationships among dietary protein and essential amino acid (AA) levels, the frequency of enteritis and concentration of certain indicators of stress in the blood. Sudden changes of feed type, incomplete development of the enzymatic equipment that allows piglets to digest dietary nutrients, as well as an imbalanced supply of nutrients, cause feeding stress, which, associated with social and environmental stresses, generate a higher flow of free radicals in the body of the animal. Various studies have shown that the post-weaning syndrome can be associated with a high level of dietary protein, which provides a substrate for pathogen bacteria to proliferate (Nyachoti et al., 2006; Wellock et al., 2008; Kim et al., 2012). The immediate effects in this situation are higher fermentation in the hindgut of undigested protein from the gastro-intestinal tract, which produces a state of disease in the form of watery faeces (Wellock et al., 2008). This state of stress can cause feeding, physiological and immunological disturbances (Leliveld et al., 2013; Pluscke, 2013). Knowledge about the mechanisms that cause disturbance in the organisms of piglets at various moments before or after weaning is limited (Colson et al., 2012).

The purpose of this study was to investigate the reaction of piglet organisms during the weaning period to a $10 \%$ decrease of dietary protein, with a concomitant possible reduction in the level of essential AAs (lysine, methionine + cystine) by $10 \%$. The focus was on investigating changes in the concentration of certain indicators, the interrelationships among them, the incidence of enteritis and changes in faecal composition. The three diets used in this study included protein from vegetal sources, the main one being soybean meal. As an alternative to fish meal - a classic yet expensive high-protein source that is banned for some species - the authors used corn gluten, which has a protein level close to that of fish meal. During this 
stage of piglet growth the enzymes that digest the protein from soybean meal are incompletely developed, so powdered milk, with highly digestible protein, was introduced into the feed formulation.

\section{Material and Methods}

The animals were supplied by INCDBNA Balotesti Experimental Farm, Romania. Conducting the experiment, managing weaning and collecting blood and manure samples were done in accordance with the protocol adopted by the Ethical Committee of the National Research-Development Institute for Animal Nutrition and Biology Balotesti. The procedures were in agreement with Council Directive 2010/63/EU legislation for the protection of animals used for scientific purposes. No antibiotic treatment was supplied to the animals throughout the experiment.

The experiment was performed in winter (February - March) on 18 hybrid (female Large White $x$ Hybrid (Large White $x$ Pietrain)) $\times$ male Talent (mainly Duroc), that is, eight female and 10 male piglets, farrowed by two sows, weaned at $30 \pm 3$ days. The animals used in the experiment did not show any indications of diarrhoea. They were kept in iron stalls with an area of $2.25 \mathrm{~m}^{2}$, and flooring provided a sleeping area. The piglets were assigned randomly to three groups (six animals per group) (Figure 1).

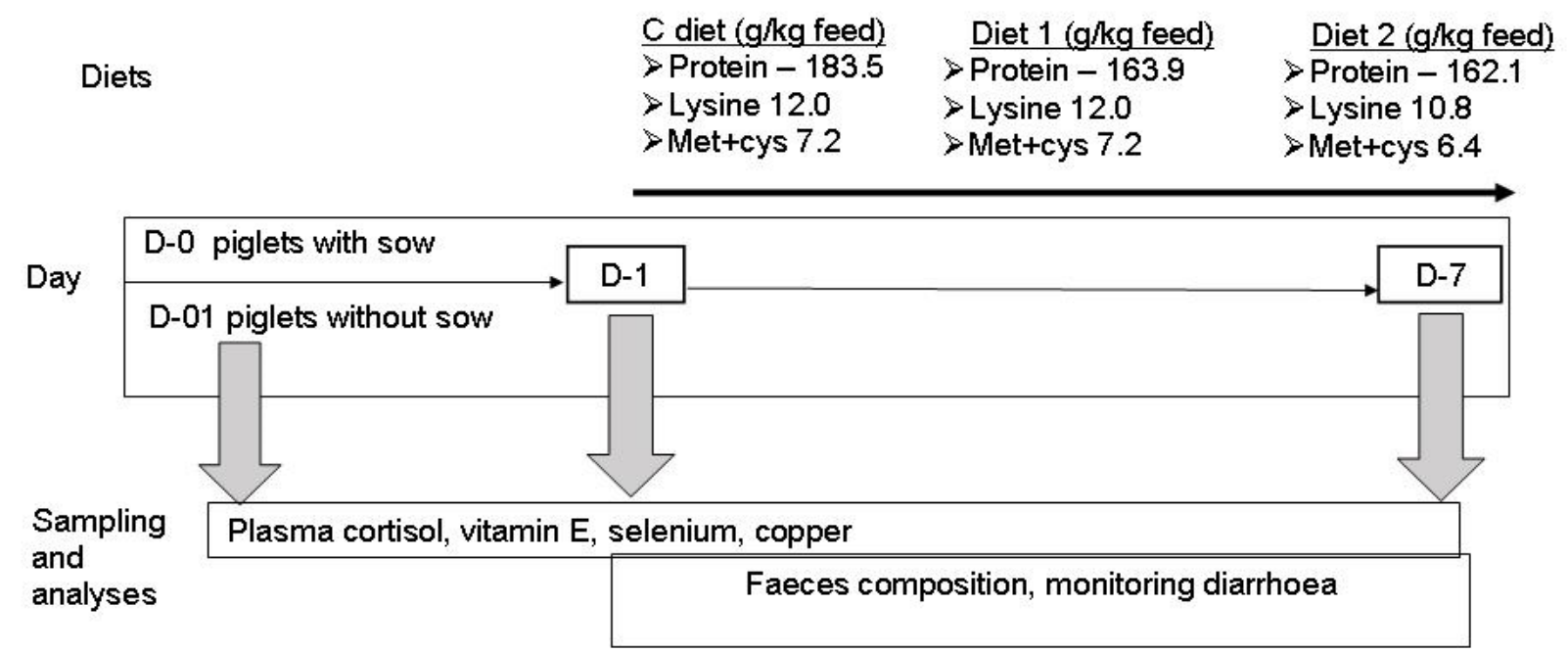

Figure 1 Experimental design

The piglets had an average initial bodyweight of $7 \pm 0.6 \mathrm{~kg}$. The feed formulation was thus designed to meet the requirements of Topigs hybrid, as specified by the guide (Table 1). The piglets from the control group ( $C$ diet) received a diet similar to that supplied in the farrowing unit, while the diet for the animals from the experimental groups 1 (diet 1) and 2 (diet 2) had a lower level of protein-rich ingredients (soybean meal, maize gluten, milk powder), and the maize level was increased (Table 1). The animals were fed ad libitum. The diet was supplied in the form of flour for two meals per day. The intake and refused feed were recorded daily. In this study the variable was the protein level, which was decreased by $10 \%$ for diets 1 and 2 compared with the $\mathrm{C}$ diet. In diet 1 , the level of essential AAs (lysine and methionine + cystine) was similar to that of the $C$ diet, but was $10 \%$ lower in diet 2 compared with diets $C$ and 1 (Figure 1 ). All formulations of compound feeds used synthetic AA, DL-methionine and L-lysine, either at a level that covered the requirements or on a different level that was used to determine the effects of the diet. The contents of metabolisable energy, calcium and phosphorus were similar in all three diets. Vitamins and minerals were supplied by a vitamin-mineral premix, added in the proportion of $1 \%$ for all diets, which had the same composition (Table 1). Vitamin E, Se and $\mathrm{Cu}$ were supplied according to the requirements for this particular age in similar amounts for all three diets. The intake of vitamin E, Se and Cu was the same in all three groups of animals. Calculating the intake of vitamin $\mathrm{E}$, Se and $\mathrm{Cu}$ took into consideration the dietary content of these elements and the average daily feed intake. The animals had free access to water via drinking nipples.

The piglets spent the first day (D-01 and D-0) in the farrowing unit, and on the second day were transferred to the nursery. Blood samples were collected from 18 piglets by jugular venipuncture the day after transfer to the nursery (D-1) and on the seventh day after weaning (D-7). In the farrowing unit, before (D-0) and after separation from their sows (D-01), blood samples were collected from four piglets and assayed for stress indicators, cortisol, vitamin $\mathrm{E}$, Se and $\mathrm{Cu}$, which were taken as reference values. The 
blood was collected in $6 \mathrm{~mL}$ vacutainers with separating gel and ultracentrifuged to obtain the serum. The serum cortisol and copper concentration were established by Synevo Romania Laboratory. Cortisol concentration was ascertained with an Immulite 2000 (Siemens), which is a solid-phase, competitive chemiluminescent enzyme immunoassay, with $1 \times 30$ minutes incubation cycle. Copper was determined with a Perkin Elmer Analyst 700, USA, using atomic absorption spectrophotometry (AAS). Serum Se and vitamin $\mathrm{E}$ concentrations were established at the Institut für Veterinärmedizinishe Diagnostik $\mathrm{GmbH}$, Berlin, Germany. Selenium was verified by AAS, with an Agilent Technologies GT 110/ GT 120 analyser. Vitamin E was ascertained with an Agilent Technologies 1200 analyser using high-performance liquid chromatography.

Table 1 Formulation and chemical composition of compound feeds used for hybrid Topigs piglets during weaning crisis

\begin{tabular}{|c|c|c|c|}
\hline Ingredients (g/kg as feed basis) & Control & Diet 1 & Diet 2 \\
\hline Maize & 639.9 & 691.9 & 694.3 \\
\hline Rice flour & 40.0 & 40.0 & 40.0 \\
\hline Soybean meal & 250.0 & 210.0 & 210.0 \\
\hline Maize gluten & 15.0 & 5.0 & 5.0 \\
\hline Milk replacer & 10.0 & 5.0 & 5.0 \\
\hline DL-methionine & 1.0 & 1.5 & 0.7 \\
\hline L-lysine & 3.3 & 4.9 & 3.3 \\
\hline Calcium carbonate & 16.3 & 16.5 & 16.5 \\
\hline Monocalcium phosphate & 12.5 & 13.2 & 13.2 \\
\hline Salt & 1.0 & 1.0 & 1.0 \\
\hline Premix cholin ${ }^{\mathrm{e}}$ & 1.0 & 1.0 & 1.0 \\
\hline Vitamin-mineral premix ${ }^{2}$ & 10.0 & 10.0 & 10.0 \\
\hline \multicolumn{4}{|l|}{ Chemical composition (g/kg feed) $^{1}$} \\
\hline Dry matter & 882.4 & 881.4 & 881.2 \\
\hline Metabolisable energy (MJ /kg) & 13.31 & 13.27 & 13.30 \\
\hline Crude protein & 183.5 & 163.9 & 162.1 \\
\hline Lysine & 12.0 & 12.0 & 10.8 \\
\hline Lysine $D^{3}$ & 10.2 & 10.4 & 9.1 \\
\hline Methionine + cystine & 7.2 & 7.2 & 6.4 \\
\hline Methionine + cystine $\mathrm{D}^{3}$ & 6.1 & 6.1 & 5.4 \\
\hline Calcium & 9.0 & 9.0 & 9.0 \\
\hline Phosphorus & 6.5 & 6.5 & 6.5 \\
\hline Cellulose & 35.8 & 33.6 & 33.7 \\
\hline Ether extract & 33.6 & 34.8 & 34.8 \\
\hline Copper (mg/kg) & 33.16 & 32.29 & 32.29 \\
\hline Zinc (mg/kg) & 125.34 & 124.04 & 124.09 \\
\hline Vitamin E (IU) & 56.97 & 57.39 & 57.45 \\
\hline \multicolumn{4}{|c|}{$\begin{array}{l}{ }^{1} \mathrm{ME} \text { and digestible amino acid contents were calculated based on feed composition and theoretical } \\
\text { coefficients. } \\
{ }^{2} \text { Vitamin mineral premix added at } 1 \% \text { to the diet contained (/kg feed): } 10000 \mathrm{IU} \text { vitamin } \mathrm{A} ; 2000 \mathrm{IU} \text { vitamin } \mathrm{D}_{3} ; \\
30 \mathrm{IU} \text { vitamin } \mathrm{E} ; 3 \mathrm{mg} \text { vitamin } \mathrm{K}_{3} ; 2 \mathrm{mg} \text { vitamin } \mathrm{B}_{1} ; 6 \mathrm{mg} \text { vitamin } \mathrm{B}_{2} ; 20 \mathrm{mg} \text { vitamin } \mathrm{B}_{3} ; 13.5 \mathrm{mg} \text { vitamin } \mathrm{B}_{5} ; \\
3 \mathrm{mg} \text { vitamin } \mathrm{B}_{6} ; 0.06 \mathrm{mg} \text { vitamin } \mathrm{B}_{7} ; 0.8 \mathrm{mg} \text { vitamin } \mathrm{B}_{9} ; 0.05 \mathrm{mg} \text { vitamin } \mathrm{B}_{12} ; 10 \mathrm{mg} \text { vitamin } \mathrm{C} ; 30 \mathrm{mg} \mathrm{Mn} ; \\
110 \mathrm{mg} \mathrm{Fe;} 25 \mathrm{mg} \mathrm{Cu} ; 100 \mathrm{mg} \mathrm{Zn} ; 0.38 \mathrm{mg} \mathrm{l} ; 0.36 \mathrm{mg} \mathrm{Se} ; 0.3 \mathrm{mg} \mathrm{Co} ; 60 \mathrm{mg} \text { antioxidant (oxitec). } \\
{ }^{3} \mathrm{D} \text { : digestible; Based on } \mathrm{AA} \text { composition of the ingredients and the digestibility coefficients determined } \\
\text { by INCDBNA Balotesti. }\end{array}$} \\
\hline
\end{tabular}


Pig faeces samples were collected once a day in petri dishes for the first seven days and stored at $-4{ }^{\circ} \mathrm{C}$ until analysed for mineral composition, bacterial and fungal populations. The mineral composition was determined at INCDBNA Balotesti with analytical purity reagents supplied by Merck (Darmstadt, Germany). Standard solutions of 1000 ppm traceable to SRM from NIST were used for calibration. The analyses were done with an absorption spectrometer, namely Solaar M6 Dual Zeeman Comfort (Thermo Electron Ltd., Cambridge, UK), a UV-Vis spectrophotometer Jasco V530 (Tokyo, Japan) and a microwave digestion system with remote temperature measurement by Berghof speedwave MWS-2 Comfort (Berghof, Eningen, Germany). Class A glassware was used for transvasation, dilution, and storage. Piglet faecal samples of 0.4 $\mathrm{g}$ each were weighed with $\pm 2 \times 10^{-4} \mathrm{~g}$ accuracy. Each sample was processed as previously described (Untea et al., 2012) and a blank digest was carried out in the same way. The samples were analysed for Ca, $\mathrm{Mg}, \mathrm{Cu}, \mathrm{Zn}$ concentrations with flame atomic absorption spectrometry after the microwave digestion. The $\mathrm{P}$ concentration was established with UV-Vis spectrophotometry. To ascertain the nitrogen ( $\mathrm{N}$ ) level, the samples were digested with $\mathrm{H}_{2} \mathrm{SO}_{4}$ in the presence of catalysers, followed by distillation and titration. The semiautomatic Kjeldahl method was carried on a Kjeltec Auto 1030 Analyser (Hillerod, Denmark).

The numbers of microorganisms from the faeces were established in INCDBNA Balotesti by counting the colonies on selected media for each microorganism. The result was expressed as a logarithm (base 10) of colony-forming units per gram of sample.

The animals were monitored daily to identify the piglets with diarrhoea. The faeces of every animal were examined visually. A subjective scoring system was used to determine the severity of diarrhoea, ranging from 1 to 4: 1: firm faeces; 2: soft; 3: mild diarrhoea; 4: severe diarrhoea. The incidence of diarrhoea was expressed as the average number of days with diarrhoea related to the total monitoring days (seven days).

The data were expressed as mean values and standard error of the mean (SEM) and submitted to variance analysis using the general linear model (GLM), SPSS Statistics version 20.0 (2011). All the data for the serum indicators were converted to the same measuring unit to make data interpretation easier. No significant interaction was noticed between the two factors of influence. The faeces were analysed for the total content of mineral elements (total N, Ca, P, Mg, Cu, Zn), bacteria (total germ count, Escherichia coli, Salmonella) and total number of fungi. The individual was regarded as the experimental unit in serum determination, while the group was considered the experimental unit in faeces determination. SPSS Pearson's correlation ( $r$ ) was used to establish the interrelations between the sets of data.

\section{Results and Discussion}

Management procedures of modern pig production systems include several actions that are potential stress generators and have known implications for the internal mechanisms of the animal organism. Generally, the effects of stress-generating factors become visible in piglet behaviour in the early postweaning days, which is why the present study used a seven-day period to evaluate piglet welfare, as reflected in their health status. The composition of feedstuff and feeding management are critical factors that influence the health state of piglets after weaning (Lallès, 2008).

Table 2 shows the effects of the lower protein level following maintenance of essential AAs (lysine, methionine + cystine) at the level of requirements (diet 1), or 10\% reduction (diet 2) of the serum concentration of cortisol, vitamin $\mathrm{E}$, Se and $\mathrm{Cu}$ on days 1 and 7 . The corresponding values during farrowing unit (before, D-0 and after separation of their mother, D-01) were taken as reference values. When piglets are separated from their mothers, they are affected emotionally, which the organism perceives as a threat to homeostasis. The piglets showed large differences in their individual capacity to cope with a stressing situation, irrespective of the analysed parameter. In this study, as response by the piglets to emotional stress, the authors noticed changes of certain serum parameters (cortisol, vitamin E, Se and Cu) that are known for their positive effects on resistance to disease during the weaning crisis (Sivertsen et al., 2007; Wang et al., 2012,). Separation from the sow induced increases in concentration of $26 \%$ serum cortisol, $6.8 \%$ Se and $5.40 \% \mathrm{Cu}$. The increased values of these indicators might be the result of an innate mechanism to alleviate effects triggered by stress-generating factors on the subsequent development of the piglets. The transfer of piglets to the nursery, where environmental conditions were close to those of the farrowing unit, added stressing stimuli, including nutritional factors. Except for vitamin $\mathrm{E}(P=0.02)$, the serum parameters did not differ $(P>0.05)$, whatever the diet. Individual variations might be owing to individual state of health and correlated with it by feed intake. After seven days the protein restriction, associated or not with that of $\mathrm{AA}$, established a reduction $(P=0.02)$ of the serum concentration of vitamin $\mathrm{E}$, irrespective of feeding treatment. Many authors have reported that one of the effects of weaning is a decrease in the plasma level of vitamin E (Meyer et al., 1981; Bonnette et al., 1990; Sivertsen et al., 2007), owing to the lower activity of carboxylester hydrolase enzyme in the gut (Sivertsen et al., 2007). 
Table 2 Mean of serum indicator concentration (cortisol, vitamin $E$, selenium and copper, $\mu \mathrm{g} / \mathrm{dL}$ ) in weaning piglets

\begin{tabular}{|c|c|c|c|c|c|c|c|c|c|c|c|}
\hline \multirow{3}{*}{ Variable } & \multicolumn{8}{|c|}{ Day*I Diets } & \multirow{3}{*}{ SEM } & \multicolumn{2}{|c|}{$P$-value ${ }^{* *}$} \\
\hline & D-0 & D-01 & \multicolumn{3}{|c|}{ D-1 } & \multicolumn{3}{|c|}{ D-7 } & & \multirow{2}{*}{$\begin{array}{l}\text { Diet } \\
\text { effect }\end{array}$} & \multirow{2}{*}{$\begin{array}{l}\text { Day } \\
\text { effect }\end{array}$} \\
\hline & \multicolumn{2}{|c|}{$\begin{array}{c}\text { Reference } \\
\text { value }\end{array}$} & Control & $\begin{array}{c}\text { Diet } \\
1\end{array}$ & $\begin{array}{c}\text { Diet } \\
2 \\
\end{array}$ & Control & $\begin{array}{c}\text { Diet } \\
1 \\
\end{array}$ & $\begin{array}{c}\text { Diet } \\
\mathbf{2} \\
\end{array}$ & & & \\
\hline Cortisol & 1.71 & 2.17 & 2.43 & 1.58 & 1.31 & 1.68 & 1.42 & 2.27 & 0.14 & 0.21 & 0.70 \\
\hline Vitamin E & 252.5 & 250.0 & 190.0 & 157.5 & 255.0 & 180.0 & 143.8 & 235.0 & 1.65 & 0.02 & 0.12 \\
\hline Selenium & 10.67 & 11.40 & 11.40 & 12.08 & 11.25 & 12.0 & 13.73 & 11.80 & 0.33 & 0.18 & 0.11 \\
\hline Copper & $132.9^{\mathrm{a}}$ & 140.0 & 154.0 & 181.3 & 179.3 & 182.1 & 183.9 & 165.4 & 6.85 & 0.67 & 0.04 \\
\hline
\end{tabular}

* Blood sample collection: D-0: in farrowing unit, before separation from the sows; D-01: in farrowing unit, after separation from the sows; D-1: one day after separation from the sows, after transfer to nursery; D-7: 7 days after weaning.

** Means within a row did not differ significantly at $P<0.05$.

The results of the current study agree with those of Robert et al. (2009) for serum Se, where concentration increased slightly $(P=0.18)$, irrespective of the diet, but disagree with those for $\mathrm{Cu}$. When the dietary concentration of AA was maintained at the level of requirements, but the supply of protein was limited, serum $\mathrm{Cu}$ concentration displayed the same trend to increase, and in the $\mathrm{C}$ diet, but less pronounced. Amino acid restriction associated with protein limitation decreased serum $\mathrm{Cu}$ by $8.4 \%$ after seven days compared with diet 2, D-1. The Cu concentration that was established in the current study was similar to that ascertained by Hill et al. (2000), but was contrary to the data reported by Robert et al., (2009) who stated that the $\mathrm{Cu}$ concentration remained stable. Boma \& Bilkei (2009) showed that $\mathrm{Cu}$ absorption is regulated by homeostatic mechanisms. The authors' results confirm this information, meaning that the feeding factor (that is, deficiency in one or several nutrients) could affect the absorption or excretion of certain parameters that are part of multi-enzymatic systems. A slightly higher availability of Se (by $9 \%$ compared with D-0 and by $2.1 \%$ compared with D-01) was observed in the present study. A high postweaning concentration of serum Se, as Robert et al. (2009) stated, may be owing to the synthesis of glutathione peroxidase, with Se as metallic co-factor, but also $\mathrm{Cu}$, in response to the high level of free radicals. Because dietary AA was maintained at the level of requirements, despite limiting the protein and maintaining the other nutrients, this allowed the animal organism to self-regulate defence mechanisms against oxidative stress, enabling higher bioavailability of several factors involved in the reduction or elimination of the free radicals. On the contrary, the dietary protein limitation, associated with AA restriction, affected the concentration of these parameters, which suggests that the animal organism does not have enough self-regulatory mechanisms in feeding deficiencies. No interaction $(P>0.05)$ was noticed between the diet and the day of sample collection.

The cortisol was positively correlated with vitamin $\mathrm{E}(r=0.394)$, and negatively correlated with $\mathrm{Cu}$ $(r=-0.385)$, both correlations being significant $(P=0.038$ for vitamin $\mathrm{E}$ and $P=0.043$ for $\mathrm{Cu}$ ). While vitamin E concentration decreased by $\sim 43 \%$ up to day 7 , Se concentration increased slightly (by $17.24 \%$ in D-7 compared with D-0). As expected, the authors observed a significant correlation between vitamin $E$ and Se $(P=0.046)$, but this correlation was not synergic, being negative $(r=-0.381)$. McDowel et al. (1977) showed that findings regarding the influence of vitamin $\mathrm{E}$ on the storage of Se in the body are contradictory. The individual limits of variation were larger in vitamin E compared with Se. The literature, as Sivertsen et al. (2007) showed, does not specify the thresholds at which vitamin E or Se could be in excess or deficient. Furthermore, vitamin E was highly significantly correlated with $\mathrm{Cu}(P=0.002)$, similar to the study of Robert et al. (2009), even if in the present study the values were higher.

Table 3 shows the average composition in dry matter (DM) and mineral elements (total $\mathrm{N}, \mathrm{Cu}, \mathrm{Zn}, \mathrm{Ca}$, $\mathrm{Mg}$ and $\mathrm{P}$ ) of the faeces samples collected for seven days from Topigs piglets.

Current feeding strategies aim to decrease the level of excreted minerals as support for environmental protection. Previous studies (Carlson et al., 2004; Li et al., 2006; Shelton et al., 2008) regarded higher dietary mineral levels (such as $\mathrm{Cu}$ and $\mathrm{Zn}$ ) as means to improve piglet health and performance. Exceeding particular levels, however, leads to higher amounts of excreted minerals owing to the homeostatic mechanisms that regulate the concentration of minerals in the tissues (Creech et al., 2004) and even to toxic effects, in the case of $\mathrm{Cu}$, which prompted the need for further research to decrease the level of this trace 
Table 3 Mean dry matter (DM) and mineral composition of faeces samples collected for seven days from weaned Topigs piglets ${ }^{1}$

\begin{tabular}{lccccccc}
\hline Group & $\begin{array}{c}\text { DM } \\
\text { \% }\end{array}$ & $\begin{array}{c}\mathbf{C u}^{2} \\
\mathbf{m g} / \mathbf{k g}\end{array}$ & $\begin{array}{c}\mathbf{Z n}^{2} \\
\mathbf{m g} / \mathbf{k g}\end{array}$ & $\mathbf{N}$ total & $\begin{array}{c}\mathbf{C a} \\
\%\end{array}$ & $\begin{array}{c}\mathbf{P} \\
\%\end{array}$ & $\begin{array}{c}\mathbf{M g} \\
\mathbf{\%}\end{array}$ \\
\hline Control & 20.37 & 139.63 & 332.16 & 1.23 & 2.17 & 2.16 & 0.56 \\
Diet 1 & 22.26 & 136.83 & 342.99 & 1.19 & 2.29 & 2.24 & 0.55 \\
Diet 2 & 20.91 & 130.29 & 344.73 & 1.06 & 1.97 & 2.26 & 0.55
\end{tabular}

${ }^{1}$ Fresh faeces samples were collected daily from each cage, homogenized to obtain an average sample, and stored at $-4{ }^{\circ} \mathrm{C}$ until analysed.

2 The levels of $\mathrm{Cu}$ and $\mathrm{Zn}$ from the excreta were closely correlated with those of the DM $(r=0.79$, and $r=0.96$, respectively).

mineral (Creech et al., 2004; Boma \& Bilkey, 2009). Ritchie et al. (1963) specified that a high dietary protein level may decrease $\mathrm{Cu}$ toxicity. Without changing the inclusion amounts of these minerals, in the current study the authors monitored the excreta of minerals under conditions of feeding stress. The DM content of diet 1 was $9.2 \%$ higher than that of group $C$ and $6.4 \%$ higher than diet 2. As expected, protein limitation decreased the amount of excreted nitrogen and, even more so, when it was associated with the decrease of the limiting $A A$ (< by $16 \%$ compared with $C$ group and by $12.2 \%$ compared with diet 1 ). Whereas the level of $\mathrm{Cu}$ decreased compared with $\mathrm{C}$ diet in both groups with feeding restriction, the level of $\mathrm{Zn}$ increased, probably owing to different enzymatic assimilation of the two trace minerals. The amount of excreted $\mathrm{Zn}$ was $3.7 \%$ higher for diet 2 compared with diet $\mathrm{C}$, while the amount of excreted $\mathrm{Cu}$ was $7 \%$ higher. There is a close correlation between the intake and excretion of $\mathrm{Cu}(r=0.75)$ and $\mathrm{Zn}(r=-0.99)$, the regression analysis showing that $R^{2}=0.28$. Magnesium was not affected by the feeding factor, while $\mathrm{Ca}$ and $\mathrm{P}$ displayed close values.

During the post-weaning period, several factors cause diarrhoea in freshly weaned piglets. The main cause, next to feeding, is the presence of Escherichia coli bacteria and of members of the genera Clostridium, Lawsonia and Brachyspira (Vondruskova et al., 2010). Previous studies have shown that the post-weaning defence mechanisms of piglets are overstressed by the oxidation phenomenon, which hampers their potential to resist stress and infections, particularly Salmonella and E. Coli (Guerra-Ordaz et al., 2013). In the present study, seven days after weaning the authors determined the bacterial and fungal composition of the faeces. The experimental animals were not treated with antibiotics or other additives (proor prebiotics, enzymes, etc.) that could influence beneficially the composition of intestinal microflora. Figure 2 shows the effects of decreasing the dietary protein level associated with the maintenance or decrease of the level of limiting AA, as well as the effect of sampling day, on the bacterial and fungal composition of the faeces.

The score of diarrhoea severity was added on the vertical axis, since these indicators of faecal contamination are correlated. The values recorded for the bacteria and fungi were within normal limits. Furthermore, Salmonella colonies were detected only on day 2 in group $C$ and diet 2, on day 5 in group C and on day 6 for diet 1 . The total count of mesophilous aerobe germs (TGC), and of the pathogen bacteria Escherichia coli and Salmonella, as well as the total fungal count (TFC) did not differ $(P>0.05)$ irrespective of dietary treatment. Colonies of Aspergillus niger, Mucor, Rhizopus fungi and of yeast were identified in the samples of faeces. The sampling day influenced $(P<0.01)$ the germs and fungi. After day 2 of sampling, the values decreased, irrespective of the type of contaminant. As expected, there was a tight relationship between TGC and Escherichia coli $(r=0.82)$, and a weaker one between Salmonella and TGC $(r=0.12)$ or Escherichia coli $(r=0.21)$. The Pearson correlation differed $(P<0.01)$ between TGC and TFC.

Significant differences in the scores of faeces consistency $(P=0.02)$ were noticed between days 1 and 2 (D1 and D2) of sampling. Throughout the period of sampling the authors noticed a non-significant trend $(P=0.08)$ that diet influences faeces consistency. These observations are in agreement with those reported by Sorensen et al. (2009), the protein limitation decreasing by $7.8 \%$ the score of faeces consistency. However, when protein restriction was associated with AA restriction, the score of faeces consistency increased by $13.7 \%$ compared with the $C$ diet. There was a positive correlation between the faecal score and germs or fungi. Sorensen et al. (2009), noticed a correlation between faeces DM, vitamin E and the faecal score. An adequate level of vitamin E protects the piglets against enteritis (Lauridsen \& Jensen, 2005), this vitamin being important for the immune system (Sorensen et al., 2009). Furthermore, 
there is a correlation between DM and the faecal score: as the DM decreases, the score of faeces consistency increases, as the authors also noticed in the present study. During the first seven days after weaning the authors noticed an important reduction in the serum concentration of vitamin $E$, but probably not at a level that might endanger piglets' health, and/or its decline had been compensated by the higher concentration of Se, irrespective of diet, and $\mathrm{Cu}$ in the case of diets $\mathrm{C}$ and 1.

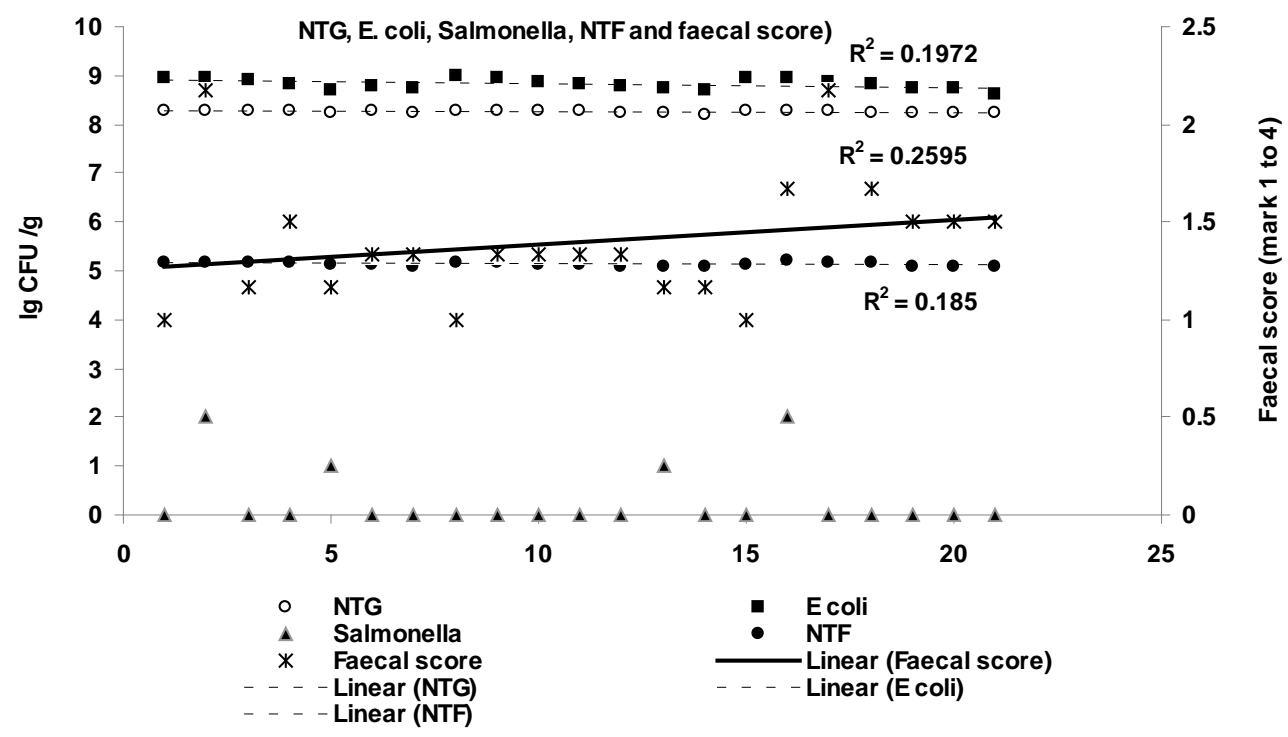

Figure 2 Dynamics of bacteriological and fungal changes in faeces and diarrhoea severity score caused by protein restriction associated or not with restriction of limiting AA in Topigs piglets during first seven days after weaning.

NTG: total count of mesophilous aerobe germs (lg CFU/g); NTF: total fungal count (lg CFU/g). The following fungi species were identified: Aspergillus niger, Mucor, Rhizopus, yeast. The consistency score was on a scale from 1 to 4: 1: firm faeces; 2: soft faeces; 3: mild diarrhoea; 4: severe diarrhoea.

Incidence of diarrhoea

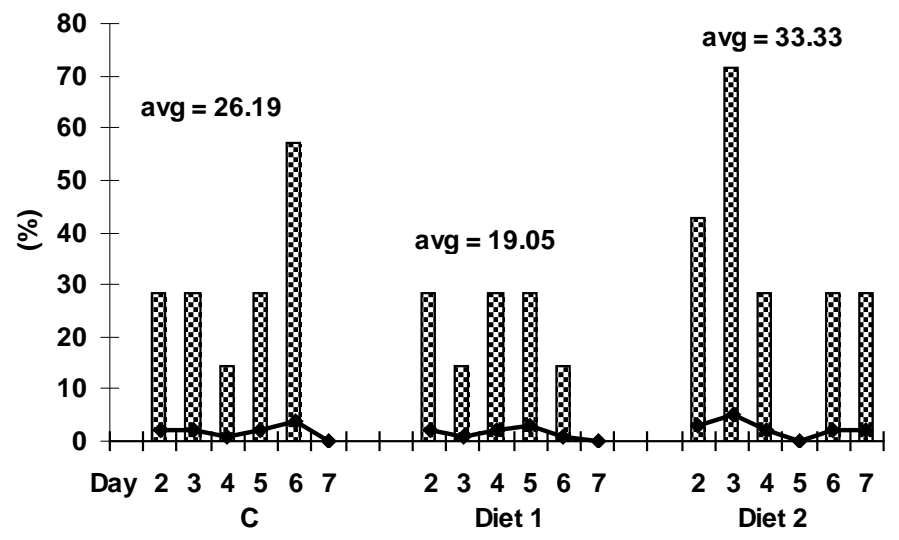

\$O Incidence of diarrhoea $\longrightarrow$ Days with diarrhoea

Figure 3 Incidence of diarrhoea in weaned piglets depending on treatment.

The animals were monitored daily to identify the piglets with diarrhoea. The faeces of every animal were examined visually. The incidence of diarrhoea was expressed as average number of days with diarrhoea related to the total monitoring days (seven days). 
The incidence of enteritis, shown in Figure 3, suggests that the post-weaning period was not characterized by serious health problems in the present study. With some exceptions, the score of faeces consistency and the incidence of enteritis did not hint at serious health problems.

When the protein level was decreased, but with no restriction of AA, the frequency of enteritis decreased 1.37 times compared with the $C$ diet, while the restriction of dietary protein and AA levels increased 1.27 times the frequency of enteritis.

\section{Conclusions}

Maintaining a dietary protein at a particular level can have a beneficial effect on health status and may limit environmental nitrogenous load. Various stressing factors (social, environmental and nutritional) may affect certain serum parameters known for their beneficial effects on the health state of the piglets during the critical stage of their development. The organisms of the piglets reacted differently to the stress-generating factors. The main contribution of this study consists in the assessment of piglets' response to stress, quantified by the level of certain indicators and health state. The information offers scientific support for further research to reduce stress, as well as to formulate optimum diets in order to avoid the waste of protein.

\section{Acknowledgments}

This study was financed by the Ministry of Agriculture and Rural Development through project ADER 721: Substantiation of Support for Ensuring Better Welfare Standards for Farm Animals, according to Art. 40 of Regulation (CE) 1698/2005.

\section{References}

Boma, M.H. \& Bilkei, G., 2009. The effects of low levels of dietary trace minerals on the plasma levels, faecal excretion, health and performance of pigs in a hot African climate. Onderstepoort J. Vet. Sci. 76, 291-297.

Bonnette, E.D., Kornegay, E.T., Lindemann, M.D. \& Notter, D.R.,1990. Influence of two supplemental vitamin $E$ levels and weaning age on performance, humoral antibody production and serum cortisol levels of pigs. J. Anim. Sci. 68, 1346-1353.

Carlson, M.S., Boren, C.A., Wu, C., Huntington, C.E., Bollinger, D.W. \& Veum, T.L., 2004. Evaluation of various inclusion rates of organic zinc either as polysaccharide or proteinate complex on the growth performance, plasma, and excretion of nursery pigs. J. Anim. Sci. 82, 359-1366.

Colson, V., Martin, E., Orgeur, P. \& Prunier, A., 2012. Influence of housing and social changes on growth, behaviour and cortisol in piglets at weaning. Physiol. Behav. 107, 59-64.

Creech, B.L., Spears, J.W., Flowers, W.L., Hill, G.M., Lloyd, K.E., Armstrong, T.A. \& Engle, T.E., 2004. Effect of dietary trace mineral concentration and source (inorganic vs. chelated) on performance, mineral status, and fecal mineral excretion in pigs from weaning through finishing. J. Anim. Sci. 82, 2140-2147.

Directive, $2010 / 63 / \mathrm{EU}$ of the European Parliament and of the Council of 22 September, 2010 on the protection of animals used for scientific purposes.

Guerra-Ordaz, A.A., Molista, F., Hermes, R.G., Gómez de Segura, A., La Ragione, R.M., Woodward, M.J., Tchorzewsk, M.A., Collins, J.W., Pérez, J.F. \& Martín-Orúe, S.M., 2013. Effect of inclusion of lactulose and Lactobacillus plantarum on the intestinal environment and performance of piglets at weaning. Anim. Feed. Sci. Technol. 185, 160-168.

Hill, G.M., Cromwell, G.L., Crenshaw, T.D., Dove, C.R., Ewan, R.C., Knabe, D.A., Lewis, A.J., Libal, G.W., Mahan, D.C., Shurson, G.C., Southern, L.L. \& Veum, T.L., 2000. Growth promotion effects and plasma changes from feeding high dietary concentrations of zinc and copper to weanling pigs (regional study). J. Anim. Sci. 78, 1010-1016.

Kim, J.C., Hansen, C.F., Mullan, B.P. \& Pluske, J.R., 2012. Nutrition and pathology of weaner pigs: Nutritional strategies to support barrier function in the gastrointestinal tract. Anim. Feed. Sci. Technol. $173,3-16$.

Lallès, J-P., 2008. Nutrition and gut health of the young pig around weaning: what news? Archiva Zootechnica 11, 5-15.

Lauridsen, C. \& Jensen, S.K., 2005. Influence of supplementation of all-rac- $\alpha$-tocopheryl acetate preweaning and vitamin C postweaning on a-tocopherol and immune responses of piglets. J. Anim. Sci. 83, 1274-1286.

Leliveld, L.M.C., Riemensperger, A.V., Gardiner, G.E., O'Doherty, J.V., Lynch, P.B. \& Lawlor, P.G., 2013. Effect of weaning age and postweaning feeding programme on the growth performance of pigs to 10 weeks of age. Livest. Sci. 157, 225-233. 
Li, X., Yin, J., Li, D., Chen, X., Zang, J. \& Zho, X., 2006. Dietary supplementation with zinc oxide increases IGF-I and IGF-I receptor gene expression in the small intestine of weanling piglets. J. Nutr. 136, 1786-1791.

McDowell, L.R., Froseth, J.A., Piper, R.C., Dyer, I.A. \& Kroening, G.H., 1977. Tissue selenium and serum tocopherol concentrations in selenium-vitamin E deficient pigs fed peas (Pisum sativum). J. Anim. Sci. 45, 1326-1333.

Meyer, W.R., Mahan, D.C. \& Moxon, A.L., 1981. Value of dietary selenium and vitamin E for weanling swine as measured by performance and tissue selenium and glutathione peroxidase activities. J. Anim. Sci. $52,302-311$.

Nyachoti, C.M., Omogbenigun, F.O., Rademacher, M. \& Blank, G., 2006. Performance responses and indicators of gastrointestinal health in early-weaned pigs fed low-protein amino acid-supplemented diets. J. Anim. Sci. 84, 125-134.

Pluske, J.R., 2013. Feed and feed additives related aspects of gut health and development in weanling pigs. J. Anim. Sci. Biotechnol. 4, 1-7.

Ritchie, H.D., Luecke, R.W., Baltzer, B.V., Miller, E.R., Ullrey, D.E. \& Hoefer, J.A., 1963. Cooper and zinc interrelation in pigs. J. Nutr. 79, 117-123.

Robert, F., Bebin, K., Garrau, J.M., Gueriot, J.F., Foret, R., Brack, M. \& Garrel, C., 2009. Evaluation et correction du stress oxydatif du porcelet en post-sevrage. Journées Recherche Porcine 41, 173-178.

Shelton, N.W., Tokach, M.D., Nelssen, J.L., Goodband, R.D., Dritz, S.S., DeRouchey, J.M., Hill, G.M., Amachawadi, R.G. \& Nagaraja, T.G., 2008. Effects of copper sulfate and zinc oxide on weanling pig growth and plasma mineral levels. Swine Day 2008, Report of Progress 1001. pp. 62-73.

Sivertsen, T., Vie, E., Bernhoft, A. \& Baustad, B., 2007. Vitamin E and selenium plasma concentrations in weanling pigs under field conditions in Norwegian pig herds. Acta Vet. Scand. 49.

Sørensen, M.T., Vestergaard, E.M., Jensen, S.K., Lauridsen, C. \& Højsgaard, S., 2009. Performance and diarrhea in piglets following weaning at seven weeks of age: Challenge with E. coli O 149 and effect of dietary factors. Livest. Sci. 123, 314-321.

Untea, A.E., Criste, R.D. \& Vladescu, L., 2012. Development and validation of a liver samples preparation method for FAAS trace elements content determination. Rev. Chim-Bucharest. 63, 341-346.

Vondruskova, H., Slamova, R., Trckova, M., Zraly, Z. \& Pavlik, I., 2010. Alternatives to antibiotic growth promoters in prevention of diarrhea in weaned piglets: a review. Vet. Med-Czech 55, 199-224.

Wang, K.-K., Cui, H.W., Sun, J.-Y., Qian, L.-C. \& Weng, X., 2012. Effects of zinc on growth performance and biochemical parameters of piglets. Turk. J. Vet. Anim. Sci. 36, 519-526.

Wellock, I.J., Fortomaris, P.D., Houdijk, J.G.M. \& Kyriazakis, I., 2008. Effects of dietary protein supply, weaning age and experimental entertoxigenic Escherichia coli infection on newly weaned pigs: health. Animal 2, 834-842. 